\title{
Adsorption of Ni (II) from Wastewater using Low Cost Activated Carbon Prepared from Prosopis Juliflora- A Kinetics and Equilibrium Studies
}

\author{
M. THILAGAVATHI ${ }^{1}$, S. ARIVOLI $^{2 *}$ andV. VIJAYAKUMARAN ${ }^{3}$ \\ ${ }^{1}$ Department of Chemistry, Pattukkottai Polytechnic College, Pattukkottai-614 601, India \\ ${ }^{2}$ Department of Chemistry, Thiru Vi Ka Government Arts College, \\ Thiruvarur-610 003, India \\ ${ }^{3}$ Anna University, University College of Engineering, Pattukkottai -614 701, India \\ vijayakumaran_66@yahoo.com
}

Received 6 February 2014 / Accepted 20 February 2014

\begin{abstract}
The optimum parameters affecting the adsorption of Ni(II) using Prosopis Juliflora bark carbon (PJBC) were determined. The adsorption of $\mathrm{Ni}$ (II) was strongly dependent on $\mathrm{pH}$, temperature and initial adsorbate concentration. The equilibrium adsorption data follows Langmuir and Freundlich isotherms. The optimum $\mathrm{pH}$ for $\mathrm{Ni}$ (II) ions removal was found out to be 5.5. The equilibrium data shows the exothermic nature of adsorption. Kinetic studies shows pseudo second order and intra-particle diffusion equations successfully describe the adsorption process.
\end{abstract}

Keywords: Adsorption, Kinetics, Nickel, PJBC, Thermodynamic

\section{Introduction}

Due to toxic heavy metals contamination water pollution has been a major problems in environment, which causes objectionable effects, impairing the welfare of the environment, reducing the quality of life and may eventually cause death. Such a substance has to be present in the environment beyond a set or tolerance limit, which could be either a desirable or acceptable limit. The industrial and domestic wastewater is responsible for causing severe damages to the environment and adversely affecting the health of the people and aquatic life. Metals can be distinguished from other toxic pollutants, since they are non-biodegradable and can accumulate in living organism. A variety of industries are responsible for the release of heavy metals into the environment through its wastewater ${ }^{1}$. These include iron and steel production, electroplating, the non-ferrous metal industry, mining and mineral processing, paint and pigment industries, leather processing, dyeing, textile and photographic industries.

The main techniques used to reduce the heavy metal ion concentration in the industrial effluents such as lime precipitation, ion exchange, adsorption using activated carbon ${ }^{2}$, 
membrane filtration and electrolytic methods. Every methods have certain limitation, since those includes high capital and operational costs and also the generation of secondary waste during the treatment process. Adsorption has advantages over other methods because it is simple, low cost and hazardous free to environment ${ }^{3}$. Activated carbon was found to be highly effective adsorbent for the removal of heavy metal ion from the concentrated and dilute metal bearing effluents ${ }^{4}$. But the process was not used by small and medium scale industries for the treatment of their metal bearing effluents, because of its high manufacturing cost. For this reason, the use of low cost materials as adsorbent for the removal of metal ion from the wastewater has been investigated. However, efforts have been contributed to develop new adsorbent and improving the existing adsorbents to have an alternative to activated carbon. The locally available Prosopis juliflora bark carbon is an alternative to commercial activated carbon.

\section{Experimental}

\section{Preparation of Prosopis Juliflora Bark Carbon (PJBC) adsorbent}

Prosopis Juliflora bark (PJB) was collected from local market. The collected PJB materials were finely powdered with grinding machine. Then the powder was treated with con. sulphuric acid for 2 hours then filtered and then washed with water. The black product was kept in a furnace for about 24 hours and the temperature was maintained at $800{ }^{\circ} \mathrm{C}$. The resulting powder was used for adsorption experiment. All other chemicals used for the experiments were highly pure.

\section{Nickel(II) ions solution}

$\mathrm{NiSO}_{4} 6 \mathrm{H}_{2} \mathrm{O}$ purchased from Merk company. The stock solution was prepared by dissolving $4.780 \mathrm{~g}$ of nickel sulphate in $1000 \mathrm{~mL}$ of distilled water.

\section{Batch method}

Batch method ${ }^{4}$ was used for adsorption and kinetic studies. The test solutions such as adsorbent, adsorbate were taken in $250 \mathrm{~mL}$ conical flasks. The solution $\mathrm{pH}$ was adjusted using a $0.1 \mathrm{~N} \mathrm{HCl}$ or $0.1 \mathrm{~N} \mathrm{NaOH}$ solution. The solution temperature was monitored using thermostatic water bath with constant stirring. The residual concentration of metal ions were measured using spectrophotometer at $455 \mathrm{~nm}$. The equilibrium parameters were used for the adsorption and kinetic studies. The amount of adsorption $\mathrm{q}_{\mathrm{t}}(\mathrm{mg} / \mathrm{g})$ at time " $\mathrm{t}$ ", amount of adsorption at equilibrium, $\mathrm{q}_{\mathrm{e}}(\mathrm{mg} / \mathrm{g})$ and percentage removal were calculated by

$$
\begin{aligned}
q_{t} & =\frac{\left(C_{O}-C_{t}\right) V}{W} \\
q_{e} & =\frac{\left(C_{O}-C_{e}\right) V}{W} \\
\% \text { Removal } & =\frac{C_{o}-C_{t}}{C_{o}} X 100
\end{aligned}
$$

Where $\mathrm{C}_{\mathrm{o}}, \mathrm{C}_{\mathrm{t}}(\mathrm{mg} / \mathrm{L})$ and $\mathrm{C}_{\mathrm{e}}(\mathrm{mg} / \mathrm{L})$ are the liquid phase concentrations of nickel ions at initial, at time and equilibrium respectively. $\mathrm{V}(\mathrm{L})$ is the volume of the solution. W $(\mathrm{g})$ is the mass of dry adsorbent used.

\section{Results and Discussion}

\section{Effect of contact time}

The effect of contact time for the removal of the metal ions using PJBC adsorbent was determined by keeping the concentration metal ions, adsorbent dose, temperature and $\mathrm{pH}$ 
were constant. The effect of contact time using $25 \mathrm{mg} / \mathrm{L}$ of metal ions, $\mathrm{pH}$ is 6 and $25 \mathrm{mg} / 50 \mathrm{~mL}$ of adsorbent at $30{ }^{\circ} \mathrm{C}$ shown in Figure 1. This indicates 60 minutes is enough to reach more than $80 \%$ removal of Nickel ions.

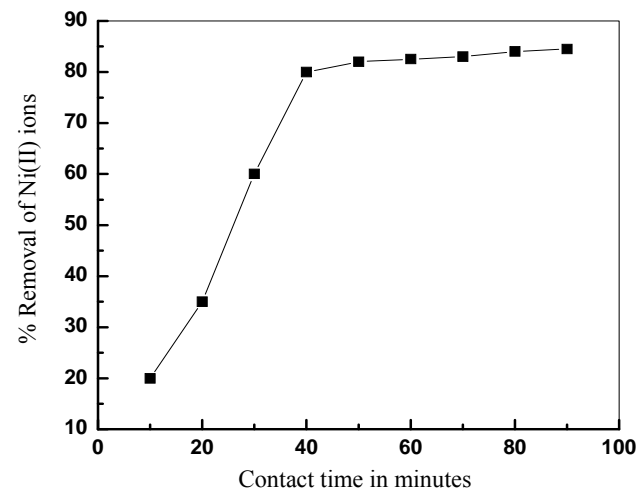

Figure 1. Effect of contact time for the adsorption of $\mathrm{Ni}(\mathrm{II})$ ions $[\mathrm{Ni}(\mathrm{II})]=25 \mathrm{mg} / \mathrm{L}: \mathrm{Temp}=30^{\circ} \mathrm{C}$; Adsorbent dose $=25 \mathrm{mg} / 50 \mathrm{~mL}$

\section{Effect of adsorbent dose}

The various doses consisting of the PJBC adsorbent were mixed with the fixed initial concentration of metal ions solution without changing the $\mathrm{pH}$ and temperature. The mixtures were agitated in a thermostatic water bath with mechanical shaker. The percentage removal of metal ions for different doses of adsorbent were determined. The effect of adsorbent dose was studied using $25 \mathrm{mg} / \mathrm{L}$ of metal ions, $\mathrm{pH}$ is $6,30{ }^{\circ} \mathrm{C}$ and adsorbent dose in the range of $5 \mathrm{mg}$ to $250 \mathrm{mg} / 50 \mathrm{~mL}$ as shown Figure 2. This indicates $25 \mathrm{mg}$ to $150 \mathrm{mg} / 50 \mathrm{~mL}$ of adsorbent dose were sufficient for this experimental concentration.

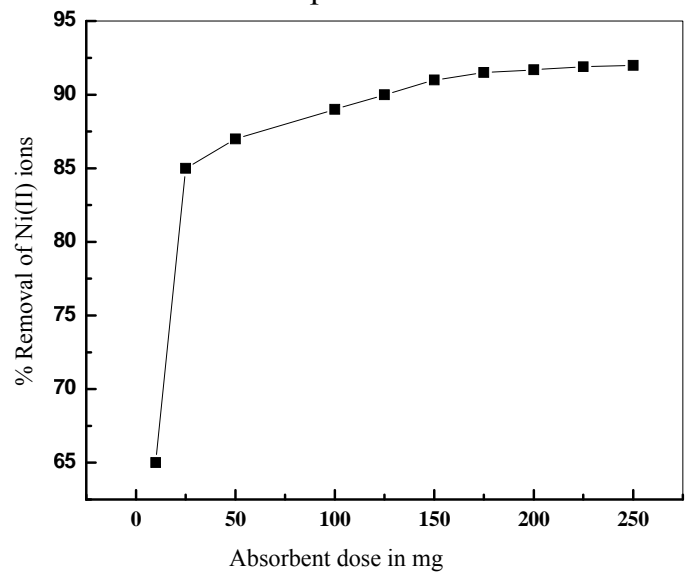

Figure 2. Effect of adsorbent dose for the removal of $\mathrm{Ni}$ (II) ions $[\mathrm{Ni}(\mathrm{II})]=25 \mathrm{mg} / \mathrm{L} ; \mathrm{pH}=6.5 ; \mathrm{Temp}=30{ }^{\circ} \mathrm{C}$; Contact time $=60$ minute

\section{Effect of solution $\mathrm{pH}$}

The mechanism of adsorption at the PJBC surface reflects the nature of physicochemical interaction of the metal ions in the solution and the active sites of the PJBC. The $\mathrm{pH}$ of the solution was varied from 2 to 10 during study. The effect of solution $\mathrm{pH}$ using $25 \mathrm{mg} / \mathrm{L}$ of 
metal ions and $25 \mathrm{mg} / 50 \mathrm{~mL}$ of adsorbent at $30{ }^{\circ} \mathrm{C}$ shown in Figure.3. The uptake capacity of PJBC is found maximum at $\mathrm{pH}$ of 5.5. It can be seen from the figure that the removal of metal ions is dependent on the $\mathrm{pH}$ of the solution.

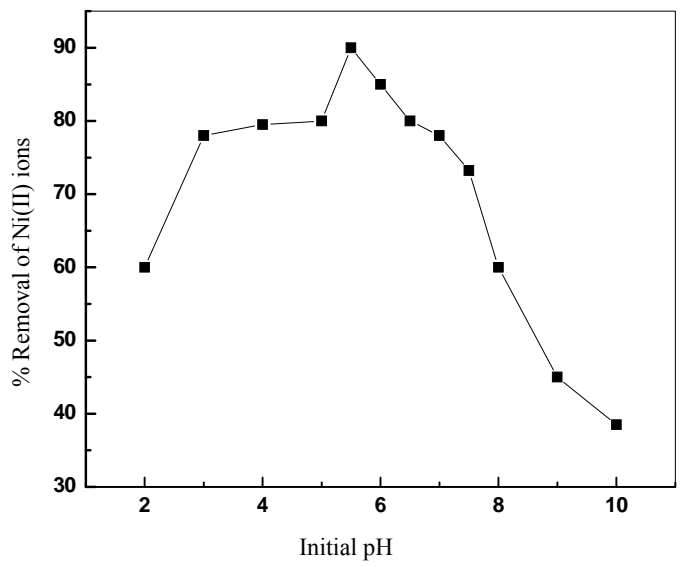

Figure 3. Effect of initial $\mathrm{pH}$ for the adsorption of $\mathrm{Ni}(\mathrm{II})$ ions using $\mathrm{PJBC}$

$[\mathrm{Ni}(\mathrm{II})]=25 \mathrm{mg} / \mathrm{L} ; \mathrm{Temp}=30^{\circ} \mathrm{C}$; Adsorbent dose $=25 \mathrm{mg} / 50 \mathrm{~mL}$; Contact time $=60$ minute

\section{Adsorption isotherms}

The Freundlich and Langmuir isotherm equations were used to calculate the adsorption capacity and energy of adsorption or intensity of adsorption. The linear form of Freundlich ${ }^{5}$ isotherm is represented by the equation

$$
\log \mathrm{q}_{\mathrm{e}}=\log K_{f}+\frac{1}{n} \log C_{e}
$$

Where $\mathrm{q}_{\mathrm{e}}(\mathrm{mg} / \mathrm{g})$ is the amount of metal ions adsorbed per unit weight of the adsorbent and $\mathrm{C}_{\mathrm{e}}(\mathrm{mg} / \mathrm{L})$ is the equilibrium concentration of the adsorbate, $\mathrm{K}_{\mathrm{f}}(\mathrm{mg} / \mathrm{g})$ is measure of adsorption capacity and $1 / \mathrm{n}$ is the adsorption intensity. The value of $\mathrm{K}_{\mathrm{f}}$ and $\mathrm{n}$ are calculated from the intercept and slope of the plot of $\log \mathrm{q}_{\mathrm{e}} v s . \log \mathrm{C}_{\mathrm{e}}$ respectively. The linear form of the Langmuir ${ }^{6}$ isotherm is given by

$$
\frac{\mathrm{C}_{\mathrm{e}}}{\mathrm{q}_{\mathrm{e}}}=\frac{1}{Q_{m} b}+\frac{C_{e}}{Q_{m}}
$$

Where $\mathrm{C}_{\mathrm{e}}(\mathrm{mg} / \mathrm{L})$ is the equilibrium concentration of the adsorbate, $\mathrm{q}_{\mathrm{e}}(\mathrm{mg} / \mathrm{g})$ is the amount of adsorbate per unit mass of adsorbent at equilibrium. The $\mathrm{Q}_{\mathrm{m}}(\mathrm{mg} / \mathrm{g})$ and $\mathrm{b}(\mathrm{L} / \mathrm{mg})$ are Langmuir constants related to adsorption capacity and energy of adsorption. The $\mathrm{Q}_{\mathrm{m}}$ and $\mathrm{b}$ are calculated from the intercept and slope of the plot $\mathrm{C}_{\mathrm{e}} / \mathrm{q}_{\mathrm{e}} v \boldsymbol{}$. $\mathrm{C}_{\mathrm{e}}$. The isotherm parameters were shown in Table.1.

Table 1. Langmuir and Freundlich parameter for nickel(II) ions using PJBC

\begin{tabular}{ccccc}
\hline \multirow{2}{*}{ Temp, ${ }^{\circ} \mathrm{C}$} & \multicolumn{2}{c}{ Langmuir } & \multicolumn{2}{c}{ Fruendlich } \\
\cline { 2 - 5 } & $\mathrm{Q}_{\mathrm{m}}$ & $\mathrm{b}$ & $\mathrm{k}_{\mathrm{f}}$ & $\mathrm{n}$ \\
\hline 30 & 146.70 & 0.2417 & 5.15 & 3.2107 \\
40 & 157.97 & 0.2352 & 5.28 & 3.1495 \\
50 & 226.00 & 0.1501 & 5.22 & 2.2809 \\
60 & 176.12 & 0.2591 & 5.60 & 3.1214 \\
\hline
\end{tabular}


From the adsorption data, it was clear that Langmuir adsorption capacity $\left(\mathrm{Q}_{\mathrm{m}}\right)$ value linearly increases up to $50{ }^{\circ} \mathrm{C}$ after that slightly decreases with increase in temperature. The increase in temperature creates more active sites on adsorbent surface. Hence monolayer adsorption and pores diffusion of $\mathrm{Ni}(\mathrm{II})$ ions were possible. Above $50{ }^{\circ} \mathrm{C}$ the monolayer was disturbed, but adsorption intensity linearly decreases up to $50{ }^{\circ} \mathrm{C}$ and then increases with raise in temperature. The Freundlich isotherm indicates that the adsorption capacity increases with increase in temperature and the $\mathrm{n}$ values indicates that the adsorption was highly favorable process.

\section{Equilibrium parameter}

The favorability of the Langmuir adsorption process expressed in terms of dimensionless separation factor or equilibrium parameter $\left(R_{L}\right)$ which is defined as

$$
R_{L}=\frac{1}{1+b C_{0}}
$$

Where $b$ is the Langmuir constant and $\mathrm{C}_{0}(\mathrm{mg} / \mathrm{L})$ is the initial concentration of the metal ions. The $\mathrm{R}_{\mathrm{L}}$ values indicate the nature of the adsorption isotherm is either linear or favorable or unfavorable or irreversible. The $\mathrm{R}_{\mathrm{L}}$ values at different temperature were calculated and given in Table 2. The $\mathrm{R}_{\mathrm{L}}$ values between 0 and 1 indicates favorable adsorption for all the initial $\mathrm{Ni}(\mathrm{II})$ ions concentrations were used.

Table 2. Equilibrium parameter $\left(\mathrm{R}_{\mathrm{L}}\right)$

\begin{tabular}{lcccc}
\hline $\mathrm{C}_{0}$ & \multicolumn{4}{c}{ Temperature } \\
\cline { 2 - 5 } & $30{ }^{\circ} \mathrm{C}$ & $40{ }^{\circ} \mathrm{C}$ & $50{ }^{\circ} \mathrm{C}$ & $60{ }^{\circ} \mathrm{C}$ \\
\hline 25 & 0.1420 & 0.1453 & 0.2104 & 0.1337 \\
50 & 0.0764 & 0.0784 & 0.1176 & 0.0717 \\
75 & 0.0523 & 0.0536 & 0.0816 & 0.0489 \\
100 & 0.0397 & 0.0408 & 0.0625 & 0.0372 \\
125 & 0.0320 & 0.0329 & 0.0506 & 0.0300 \\
\hline
\end{tabular}

\section{Thermodynamic parameters}

The standard free energy change $\left(\Delta \mathrm{G}^{0}\right)$, standard enthalpy change $\left(\Delta \mathrm{H}^{0}\right)$ and standard entropy change $\left(\Delta S^{0}\right)$ were calculated using the value of adsorption equilibrium constants $\left(\mathrm{K}_{0}\right)$ and temperature. The equilibrium constant $\mathrm{K}_{0}$ for the adsorption reaction was determined from the plot of $\ln \left(\mathrm{q}_{\mathrm{e}} / \mathrm{C}_{\mathrm{e}}\right)$ against $\mathrm{C}_{\mathrm{e}}$ at different temperatures suggested by Khan and Singh ${ }^{7}$. The value of $\Delta \mathrm{H}^{0}$ and $\Delta \mathrm{S}^{0}$ can be calculated from the slope and intercept of the plot of $\operatorname{lnK}_{0}$ against $1 / \mathrm{T}$. The free energy of adsorption process related to the equilibrium constant $\mathrm{K}_{0}(\mathrm{~L} / \mathrm{mol})$ is given by the equation

$$
\Delta \mathrm{G}^{0}=-R T \ln K_{0}
$$

Where $\Delta \mathrm{G}^{0}$ is the free energy change of adsorption $(\mathrm{J} / \mathrm{mol}), \mathrm{T}$ is the temperature in Kelvin and $\mathrm{R}$ is the universal gas constant $\left(8.314 \mathrm{~J} \mathrm{~K}^{-1} \mathrm{~mol}^{-1}\right)$. The equilibrium constant, $\Delta \mathrm{H}^{0}$ and $\Delta \mathrm{S}^{0}$ is related to the following equation

$$
\ln K_{0}=-\frac{\Delta H^{0}}{R T}+\frac{\Delta S^{0}}{R}
$$

Where $\Delta \mathrm{H}^{0}$ is the standard heat change of adsorption $(\mathrm{kJ} / \mathrm{mol})$ and $\Delta \mathrm{S}^{0}$ is standard entropy change $\left(\mathrm{J} \mathrm{K}^{-1} \mathrm{~mol}^{-1}\right)$. These parameters were given in Table 3. The negative $\Delta \mathrm{G}^{0}$ value confirmed the feasibility of the adsorption process and the spontaneous nature of 
adsorption. The negative value $\Delta \mathrm{H}^{0}$ obtained indicated the exothermic nature of the process. The positive $\Delta \mathrm{S}^{0}$ value indicates the increase in the randomness of the Ni(II) ions on PJBC surface. In this condition the adsorbed water molecules gain more translational entropy due to the displacement of the $\mathrm{Ni}(\mathrm{II})$ ions, thus allowing the increase in the randomness in the system. The magnitude of $\Delta \mathrm{S}^{0}$ suggests that the process was physical adsorption.

Table 3. Thermodynamic parameters

\begin{tabular}{|c|c|c|c|c|c|c|}
\hline \multirow[b]{2}{*}{$\mathrm{C}_{0}$} & \multicolumn{4}{|c|}{$\Delta \mathrm{G}^{0}$} & \multirow{2}{*}{$\Delta \mathrm{H}^{0}$} & \multirow{2}{*}{$\Delta \mathrm{S}^{0}$} \\
\hline & $30^{\circ} \mathrm{C}$ & $40^{\circ} \mathrm{C}$ & $50^{\circ} \mathrm{C}$ & $60^{\circ} \mathrm{C}$ & & \\
\hline 25 & -6663.04 & -7348.89 & -8121.53 & -8908.78 & -16.08 & 74.97 \\
\hline 50 & -4567.75 & -5255.83 & -5849.54 & -6726.25 & -16.81 & 70.46 \\
\hline 75 & -3232.45 & -3613.93 & -4008.59 & -4470.47 & -9.20 & 40.99 \\
\hline 100 & -1649.91 & -1997.79 & -4927.95 & -2799.22 & -18.39 & 66.76 \\
\hline 125 & -467.44 & -945.03 & -3162.89 & -1880.31 & -19.59 & 66.69 \\
\hline
\end{tabular}

\section{Adsorption kinetics}

The adsorption kinetics describes the solute uptake rate. The kinetic models such as pseudo second order and Intra-particle diffusion were used to fit the experimental data using linear fit analysis method. The pseudo second order equation explained by Ho and McKay, ${ }^{8,9}$ is

$$
\frac{t}{q_{t}}=\frac{1}{k_{2} q_{e}{ }^{2}}+\frac{1}{q_{e}} t
$$

Where $k_{2}$ is the pseudo second order rate constant $\left(\mathrm{g} \mathrm{mg}^{-1} \mathrm{~min}^{-1}\right)$. The plot of $\left(\mathrm{t} / \mathrm{q}_{\mathrm{t}}\right)$ against time should give a linear relationship from which $\mathrm{q}_{\mathrm{e}}$ and $\mathrm{k}_{2}$ can be determined from the slope and intercept of the plot, respectively. The correlation coefficients $\left(\mathrm{R}^{2}\right)$ were also calculated. The intra-particle diffusion model proposed by Weber and Morris ${ }^{10}$ is

$$
q_{t}=k_{i d} t^{1 / 2}+C
$$

Where $\mathrm{k}_{\mathrm{id}}$ is the intra-particle diffusion rate constant $\left(\mathrm{mg} \mathrm{g}^{-1} \mathrm{~min}^{-1 / 2}\right)$ and $\mathrm{C}$ is constant. The slope of the plot of $\mathrm{q}_{\mathrm{t}}$ against $\mathrm{t}^{1 / 2}$ will give the value of the intra-particle diffusion constant. The kinetic data is shown in Table.4. The correlation coefficients $\left(\mathrm{R}^{2}\right)$ were also calculated. From the kinetic data, the $\mathrm{q}_{\mathrm{e}}$ value calculated from the pseudo second order is almost equal to the experimentally calculated $\mathrm{q}_{\mathrm{e}}$ value. The rate constant value is nearly same at particular initial nickel ions concentration with high $\mathrm{R}^{2}$ value. In the intra-particle diffusion model, the pore diffusion decreases with temperature raises from 30 to $60{ }^{\circ} \mathrm{C}$ and $\mathrm{R}^{2}$ value is greater than 0.9000 . Since these two model explain the mechanism of the nickel ions adsorption.

Table 4. Kinetic parameters

\begin{tabular}{ccccccc}
\hline \multirow{2}{*}{$\mathrm{C}_{0}$} & \multirow{2}{*}{ Temp, ${ }^{\circ} \mathrm{C}$} & \multicolumn{3}{c}{ Pseudo second order } & \multicolumn{2}{c}{ Intra-particle diffusion } \\
\cline { 3 - 7 } & 30 & $\mathrm{q}_{\mathrm{e}}$ & $\mathrm{K}_{2} \times 10^{-3}$ & $\mathrm{R}^{2}$ & $\mathrm{~K}_{\mathrm{id}}$ & $\mathrm{R}^{2}$ \\
\hline \multirow{3}{*}{25} & 40 & 51.10 & 1.76 & 0.9944 & 3.651 & 0.9565 \\
& 50 & 51.82 & 3.12 & 0.9595 & 2.321 & 0.9825 \\
& 60 & 56.91 & 1.06 & 0.9991 & 2.328 & 0.9731 \\
& 30 & 96.21 & 1.09 & 0.9931 & 3.997 & 0.9346 \\
50 & 40 & 96.92 & 1.48 & 0.9969 & 6.064 & 0.9888 \\
& 50 & 98.30 & 1.50 & 0.9930 & 4.734 & 0.9869 \\
& 50 & & & & & \\
\hline
\end{tabular}




\begin{tabular}{lcccccc}
\hline \multirow{6}{*}{75} & 60 & 99.98 & 1.57 & 0.9937 & 4.575 & 0.9845 \\
& 30 & 130.95 & 0.937 & 0.9907 & 7.024 & 0.9840 \\
& 40 & 133.12 & 0.966 & 0.9917 & 6.979 & 0.9881 \\
& 50 & 135.82 & 0.948 & 0.9916 & 7.094 & 0.9875 \\
\multirow{4}{*}{100} & 60 & 137.93 & 0.991 & 0.9919 & 6.903 & 0.9818 \\
& 30 & 151.24 & 0.629 & 0.9853 & 9.324 & 0.9803 \\
& 40 & 155.93 & 0.644 & 0.9879 & 9.416 & 0.9876 \\
& 50 & 159.64 & 0.673 & 0.9885 & 9.272 & 0.9859 \\
125 & 60 & 165.00 & 0.674 & 0.9879 & 9.334 & 0.9799 \\
& 30 & 169.17 & 0.352 & 0.9277 & 12.102 & 0.8604 \\
& 40 & 169.61 & 0.551 & 0.9858 & 10.656 & 0.9863 \\
& 50 & 180.71 & 0.502 & 0.9854 & 11.485 & 0.9865 \\
\hline
\end{tabular}

\section{Conclusion}

The adsorption of $\mathrm{Ni}(\mathrm{II})$ ions from waste water using a low cost adsorbent PJBC was investigated under different experimental conditions in batch process. The maximum uptake for $\mathrm{Ni}(\mathrm{II})$ ions removal was found at $\mathrm{pH}$ of 5.5. The adsorption data fitted with both Freundlich and Langmuir adsorption isotherm. The thermodynamic parameters were found to be thermodynamically favourable physical adsorption process. The kinetic data fit with the pseudo second order and intra-particle diffusion models. The results of the present studies indicates that the PJBC could be used for the removal of $\mathrm{Ni}$ (II) ions from waste water.

\section{References}

1. Braukmann B M, Industrial Solution Amenable to Biosorption; In Biosorption (Edited by Volusky B), CRC Press, Boca Raton, FL, 1990.

2. Dean J G, Bosqui F L and Lanouette K H, Environ Sci Technol., 1972, 6(6), 518-522; DOI:10.1021/es60065a007

3. Viraraghavan T and Dronamraju M M, J Environ Sci Health Part A, 1993, 28(6), 1261-1276; DOI:10.1080/10934529309375941

4. $\quad$ Hameed B H, Krishni R R and Sata S A, J Hazard Mater., 2009, 162(1), 305-311;

5. Freundlich H, Z Phys Chem., 1906, 57, 384-470.

6. $\quad$ Langmuir I, J American Chem Soc., 1918, 40(9), 1361-1403; DOI:10.1021/ja02242a004

7. Khann A A and Singh R P, Colloids Surfaces, 1987, 24(1), 33-42; DOI:10.1016/0166-6622(87)80259-7

8. $\quad$ Ho Y S and McKay G, Water Res., 2000, 34(3), 735-742; DOI:10.1016/S0043-1354(99)00232-8

9. Ho Y S and McKay G, Chem Eng J., 1998, 70(2), 115-117; DOI:10.1016/S0923-0467(98)00076-1

10. Weber W J and Morris J C, J Sanit Eng Div., 1964, 90, 79-107. 